\title{
The Impact of the Quality of Electronic Banking Services in Achieving Customer Satisfaction from the Point of View of Al Rajhi Bank Customers
}

\author{
Mohamed Ahmed Hamadtu Ahmed ${ }^{1 \& 2}$ \\ ${ }^{1}$ Department of Business Administration, Faculty of Science and Humanities, Al-Dawadmi, Shaqra University, \\ Saudi Arabia \\ ${ }^{2}$ University of the Holy Quran and Islamic Sciences, Sudan \\ Correspondence: Faculty of Science and Humanities, Al-Dawadmi, Shaqra University, Saudi Arabia. E-mail: \\ hamto@su.edu.sa
}

Received: September 15, 2021

doi:10.5539/ijbm.v17n1p105
Accepted: November 27, $2021 \quad$ Online Published: December 15, 2021

URL: https://doi.org/10.5539/ijbm.v17n1p105

\begin{abstract}
This study aims to identify the effect of the quality of electronic banking service in achieving customer satisfaction of Al Rajhi Bank in Al Dawadmi branch by studying the dimensions of the quality of electronic banking services including tangibility, reliability, safety, empathy and response. The population of study consists of customers benefiting from the services of Al Rajhi Bank in the Kingdom of Saudi Arabia. A questionnaire was distributed to 100 individual customers of the Al Rajhi Bank. The data were, then, collected and analyzed using the SPSS statistical analysis program. The results have revealed that all the dimensions of the quality of electronic banking services namely, tangibility, reliability, safety, empathy and response are significantly related to customer satisfaction in Al Rajhi Bank. This study provides important recommendations that hopefully intended to help the bank promote the quality of banking electronic services.
\end{abstract}

Keywords: quality of electronic banking, customer satisfaction, Al Rajhi Bank

\section{Introduction}

In general, the service quality has been acknowledged to be the most important factor to stive the competitive advantage (Islam, Ahmed, Rahman, \& Al Asheq, 2021). More specifically, the quality of electronic banking services is crucial for every bank to play the role appealing to its customers (Ozkan, Suer, Keser \& Kocakoç, 2020). The quality of electronic service may also determine the bank competition ability in the banking business environment in the Kingdom of Saudi Arabia. A bank, therefore, seeks to improve its electronic banking services in order to achieve its goals and ensure its stability and continuity for the longest possible period. Service institutions, including banks, endeavor their customers' satisfaction in order to survive, compete effectively in the market, and achieve excellence in their tangible and intangible services. It is important to carefully select well-trained workers, who are able to deal well with customers and respond to their requests. In order to achieve its goals and its customer's satisfaction, Al Rajhi Bank must implement the quality of electronic banking services.

There are so many economic and social difficulties the Kingdom of Saudi Arabia challenge. It is from this point stems the importance of the roles that are played by banks to face these challenges and then to achieve the vision of the Kingdom of Saudi Arabia (20-30) through the implementation of projects that contribute to the development and improvement of the national economy, in addition to stimulating private sector investments that create new job opportunities and raise the standard of living for individuals, as well as weighting Trade balance in favor of the state. However, banks face many difficulties such as: making out the quality of electronic services, the increasing competition in this sector, the lack of studies and research related to the quality of electronic services that affect customer satisfaction, and the lack of awareness among service banks of the importance of quality in providing their services and achieving a competitive advantage. The study tends to investigate the extent to which the quality of the electronic banking service dimensions can positively affects satisfaction of Al-Rajhi Bank's (Dawadmi branch') customers. To this end, the study attempts to answer the following questions: 
1) What is the impact of tangibility on customer satisfaction of Al Rajhi Bank?

2) What is the impact of reliability on the satisfaction of Al Rajhi Bank customers?

3) What is the impact of safety on the satisfaction of Al Rajhi Bank customers?

4) What is the impact of immediate response on the satisfaction of Al Rajhi Bank customers?

The importance of this study stems from the importance of the quality of electronic banking services provided by Al Rajhi Bank and its effect/s on customers' satisfaction achievement. Because quality means focusing on and achieving customer's satisfaction; and since competition in the financial market of Saudi banks is intense, the current study is mainly intended to identify the positive aspects of customer satisfaction through the quality of basic services looked for by the customers. Exploring positive aspects of customers' satisfaction via their awareness of the impact of the quality of electronic services (reliability, tangibility, speed of response, safety and empathy), may also help the bank in sparkling, maintaining and stimulating customers' attention and interest.

\section{Literature Review}

\subsection{The Context of the Study}

Al-Rajhi Bank is considered one of the largest Islamic banks in the world. It started its activities in $1957 \mathrm{AD}$. Al Rajhi Bank has more than 60 years of experience in banking and commercial activities. And the first branch of a bank for men was opened in the Al-Dirah district in Riyadh in 1957, while the first branch for women was opened in 1979 in the Shmaisi district. To a Saudi public joint stock company. Since the bank is mainly based on the principles of Islamic banking, it plays a major and essential role in bridging the gap between The requirements of modern banking and the core values of Islamic law forming industrial and development standards to be followed. Al-Rajhi Bank, headquartered in Riyadh, Saudi Arabia, enjoys a strong financial position and manages assets worth 343 billion Saudi riyals (90 billion US dollars), and its capital is 16.25 billion Saudi riyals ( $\$ 4.3$ billion), and employs more than 10,200 employees. It has an extensive network of more than 570 branches, more than 4,794 ATMs, 74,612 point of sale machines, and 233 remittance centers. It also has the largest customer base among Saudi banks.

\subsection{Quality of Electronic Banking Services}

In recent years, the world has witnessed rapid changes in technical and technological development at the level of services provided in different sectors. The services sector occupies crucial importance due to the benefits that customers benefit from the large number and diversity of services provided in various fields, hence for here comes the urgent need for quality as an ideal means to achieve quality. Services are according to specific standards and dimensions on which they are based and specialized, and the quality of service differs from the quality of goods, and accordingly, the standards and concept of service quality differ from others and the concepts of service have varied, each according to personal viewpoints. Before we get to the concept of banking service quality, the service must be defined. as it has been known that banking service quality represents some of the things that are produced and consumed together.

According to Al-Sarn (2007), the service consists of several elements as it consists of actions and interactions that express social communication and service is more than the production of some intangible things, it is a social interaction between the producer and the customer, and this sheds light on the importance of the customer, whose needs and interactions must be taken during the production process (Al-Sarn, 2007).Moreover, Abul-Naga defines it as an intangible activity or benefit provided by one party to another, and it does not result in any ownership, and that its production or presentation is related to a tangible product or is not related to it (Abu al-Naga, 2008). As for service quality, it is a measure of the extent to which the level of service provided matches the customer's expectations. Providing a quality service means matching the customer's expectations on a consistent basis. It is also a long-term performance evaluation carried out by the customer about the service provided by the bank. The concept of service quality is based on the customer's point of view which makes it a relative measure that varies from one customer to another, and the quality of service depends on the customer's evaluation, which judges it by comparing what he has actually received with what he expects from that service (Giashi \& Haddad, 2010). Finally, the ISO (International Standard System) defined it in the two series of specifications issued by ISO14000 and ISO 9000, that quality is the extent to which the specifications of a product or service conform to the required specifications.

The importance of quality stems from the intense competition between banks providing various banking services worldwide, through the increasing demand for electronic banking services, which reflects the level of change in customer behavior and standard of living, and the development of technology methods in which services are provided and other various factors (Dradakah, 2006). They can be highlighted in the following factore. First, the 
growth of the service field: The increase in the number of commercial banks that provide services is an indicator of the growth of services provided to customers, in addition to the growth of service-related companies that are still expanding, such as telecommunications companies (fifth generation), and this leads to an increase in the level of competition between companies and then it does not remain There are only banks in the market that provide good electronic services that meet the desires and aspirations of customers benefiting from the service, and even exceed their expectations. Second, increasing competition: The survival of banks in the face of high competition depends on their ability. Therefore, they intend to provide an electronic banking service that meets the aspirations of customers, and provides them with many competitive advantages.

Third, greater understanding of customers: that customers be treated well, because they hate dealing with banks that focus only on providing service. It is not enough to provide products of quality and reasonable price without good treatment and a deep understanding of customers' requirements and expectations. Eventually, the economic significance of the quality of customer service: Banks are now keen on the need to continue dealing with them and expand their customer base, and this necessitates that they seek to attract new customers, but they must maintain existing customers, and hence the paramount importance of the quality of electronic service.

According to Daradkeh (2006), The characteristics of the service are as follows:

1. It is intangible: the customer who purchases a specific service cannot touch it before the purchase process takes place, or evaluate it or express an opinion about it through his five senses, and thus it is difficult for him to inspect it, such as banking services, electricity, telecommunications and the Internet.....etc.

2. The interdependence between the service and its provider: This means the interdependence between the service, the provider and the requester, that is, the service requester must be present in person, or at the company's window on the World Wide Web (Internet).

3. Heterogeneity: the service varies from one company to another according to the efficiency of the company providing the service, such as telecommunications companies and other different service companies.

4. Inability to store: The service cannot be stored, but rather perishes once it is used and expires, such as recharge cards in communications or the Internet

5. The right of ownership: the service differs from the commodity in the transfer of the right of ownership. In goods, ownership is transferred to one person to another as soon as the purchase process is completed, such as buying a car, then its ownership is transferred to the buyer once the purchase process is completed. As for the service, the buyers benefit from it, but its ownership is not transferred to them, such as car rental and hotels, etc.

The dimensions of the quality service can be classified into five dimensions. The first dimension is tangible elements which represent the physical appearance of facilities, equipment, personnel, and communication materials, and all of these physical elements give a mental image of the service that will be used by customers, especially new customers, to evaluate quality, and because tangible elements are usually used by service companies to enhance the mental image and continuity, and quality indicators for customers, most companies collect What is the difference between this dimension with other dimensions to form a strategy for the quality of the bank?. The second dimension is reliability (credibility), one of the previous studies indicated that the reliability criterion in service performance was the most important determinant in customers' perceptions of service quality in the United States of America, and reliability can be defined as the ability to make promises from the service provider to perform the service in an accurate and reliable manner. More broadly, reliability means that the company delivers the promises it has made to customers through marketing communications (promises related to the delivery process, additional services, problem solving and pricing) and the customer usually prefers the bank that fulfills its promises, especially with regard to the essence of the service.

The third dimension is response (speed of transaction) which can be viewed as the desire to help customers and provide fast service, and this dimension focuses on attention and speed in dealing with customer requests, complaints and problems, and the response to customers can be expressed through the length of time the customer waits for assistance or answering questions or Showing attention to the problems facing the customer, and the response can express flexibility or the ability to provide the service to the customer personally. This dimension must be dealt with from the customer's point of view and not from the company's point of view, because what the company sees may differ from the customer's vision. The fourth dimension is guarantee (trust and safety) which can be defined as the knowledge, kindness and ability of the employees of the company and its employees to create confidence and security in the hearts of customers, and this dimension is very important, especially in the case of services in which customers realize a high risk or uncertainty regarding their ability On evaluating results such as banks, health services, insurance, legal services, and others. The last one is care 
(personal attention) which can be seen as the personal care and attention that the company provides to its clients, and this dimension can be expressed by showing the client that he is special and important (by providing services personally). The client wants to feel that his needs are known, and that he is important in the eyes of The company providing the service, knowing the customers by name and building relationships with them reflects their personal knowledge of the customer's requirements and preferences.

As for the quality of the banking service, it is a difficult process compared to the quality of the goods, given that the perceived quality in the banking service differs from the quality in the tangible goods that depend on certain criteria. The bank's employees deal with the customer, in addition to confidentiality, privacy, accuracy of information and speed in providing banking service, and it is clear that there is a difficulty in finding a specific definition of banking service, and this is a result of the nature of intangible banking services, for example, there is a discrepancy in the skills of workers and the quality of customers and the difference in service delivery times.

According to Black (2016), there are many steps to achieving Quality in Banking Service. The first step is attracting attention and arousing interest in customers. Attracting customers' attention and showing interest in them through positive attitudes shown by the service provider, psychological and mental readiness to meet customers, good appearance, attractive smile, effective positive behavior and self-confidence ... etc. are all considered as a stimulus that awakens desire Customers have to get the service and get it constantly and can. The second step is creating the desire of customers and determining their needs. Creating desire and identifying the needs of customers depends on the skills of service providers. The third step is persuading the customer and addressing his objections. The process of persuading the customer to convince that service is not an easy thing, but it requires from the service provider many behavioral efforts capable of creating conviction among customers when providing services as well as addressing the objections raised by the customer. The fourth step is The service provider should listen carefully to the customer: show interest and vigilance while writing down the opinions and observations made by the customer until he is satisfied. The last step is ensuring the continuity of customers dealing with the institution: The process of ensuring the continuity of dealing with the institution and creating customer loyalty comes through some services that guarantee the loyalty of clients to the bank, such as taking care of clients' complaints and comments and others.

\subsection{Customer Satisfaction}

It is an important word in the science of marketing, and many try to know customer satisfaction by observing the reactions and sayings about the product or service. And the beneficiaries (Al Muhaidib, 2015). Studies have shown that customer satisfaction positively affects the success of for-profit and non-profit organizations; Therefore, a number of large and giant organizations pay special attention to customer satisfaction. For example, Cisco and there are many giant companies (Cisco) put a special priority on customer satisfaction as a basic policy and stresses the importance of developing quality in major companies connected to the Internet; hence, serving billions of customers on line. One of the greatest management theorists (Peter Drucker) says: "The mission of the business process is to attract and retain customers." Without trying to reach customer satisfaction, customers cannot be kept let alone others.

The main objective of customer service is to satisfy customers, gain their trust and their desire to continue dealing with the organization, to ensure the benefit of the financial returns obtained from them, in exchange for the goods and services provided by the bank and to achieve a competitive advantage among other organizations operating in the same sector. Furthermore, attracting and winning new customers, by building a strong reputation for the bank, and meticulously applying the core values, which increases the number of customers, and increases the volume and profits. In addition, achieving a competitive advantage among banks operating in the same field. Providing services on time, and fulfilling the promises and obligations undertaken by the Bank to avoid losing the customer's trust is also crucial.

Al-Tai and Al-Alaqi (2015) distinguished between service quality and customer satisfaction, as he stated that quality is a position that the customer creates during his evaluation of the service offer and that this position is often based on previous cumulative experiences. Satisfaction is the final product of the user's evaluation of a particular exchange. For example, when a client opens a savings account with a bank, the level of satisfaction achieved from this process is represented in the light of the client's expectations from the bank and the actual end product of the service provided. If the actual results of the service exceed what was expected. (For example, completing the process of opening a savings account quickly and efficiently without the customer having to wait long, he will be satisfied with the service and happy with it, otherwise he will be dissatisfied (Al-Tai \& Al-Alaqi ,2015).

The same customer can judge the quality of the savings account opening service comprehensively, by making 
comparisons with another bank, or a number of banks, to determine the quality of the service that the first bank should provide to the customer in this case, a single transaction or exchange will not be enough to judge the quality. Other researchers believe that the difference between service quality and beneficiary satisfaction lies in how to define or define the meaning of expectations. These researchers assert that when measuring perceived service quality, the level of comparison (I mean expectation pours into the crucible of what the beneficiary should expect while in measuring satisfaction The level of comparison is based on "what the beneficiary may expect from the service." In the first case (I mean what should the beneficiary expect from the service), the expectation here, with respect to, for example, a commercial bank, is based not only on the customer's previous experience related to the branches of this bank that the customer has dealt with in particular, but rather the customer's expectation and evaluation of the quality of the service of this bank is based In the second case (I mean what the beneficiary of the service might expect), the expectation is in the form of a perception or prediction based on the location of the concerned commercial bank (Al-Tai \& Al-Alaqi ,2015). The researchers confirm that the concept of customer satisfaction differs from the concept of service quality. Satisfaction results from the comparison between the expected service and the perceived service, while service quality refers to the comparison between the service requested and desired by the beneficiary and the perceived service (Ahmed, 2001).

\subsection{The Relationship between Electronic Service Quality and Customer Satisfaction}

Reviewing literature review, the link between electronic service quality and customer satisfaction is prominent. For example, the study of Al-Azzam (2015) which aimed to identify the impact of the dimensions of banking service quality represented by tangibility, reliability, safety, responsiveness and empathy on customer satisfaction in the Arab Bank, through a study The quality of the banking service was the subject of the study. The study targeted the clients benefiting from the services of the Arab Bank in the city of Irbid. The study concluded that the most important results are to achieve that the clients of the bank are satisfied with the quality of the service provided by the bank. This study proved that all the dimensions of the banking service quality including tangibility, responsiveness reliability, empathy, and security are crucial factors affecting customer satisfaction. A another study conducted by Black (2016) which aimed to measure the dimensions of the quality of banking service provided by Bank of Syria and Overseas. The study concluded that the quality of banking service affects customer satisfaction. The study recommended paying attention to advanced facilities and equipment that suit customers' needs and expectations for the services provided by the bank.

Um Al-Khair (2016) also studied the role of the quality of banking services and its impact on customer satisfaction, an applied study on the Bank of Algeria - external customers, the study aimed to know the impact of banking services on customer satisfaction, and the study concluded that there is a positive relationship between the quality of banking services and customer satisfaction, with response having the most impact and empathy the least. Alolayyan, Al-Hawary, Mohammad and Al-Nady (2018) studied the effect of the constructs of service quality on the customer satisfaction in Jordanian commercial banks. The results revealed that these dimensions namely assurance; reliability; tangibles; empathy; and responsiveness are significant predictors of customer satisfaction respectively.

The most recent study conducted Nguyen, Pham, Tran \& Pham (2020) found that all five dimensions of service quality in e-banking namely, reliability, responsiveness, service capacity, empathy and tangibility have positive correlations with customer satisfaction in commercial banks, Vietnam. Among these determinants, service capacity and tangibility have the strongest impact. Islam et al. (2021) also found that visibility, responsiveness and employee commitment are significantly associated with customer satisfaction among private banks' customers in Bangladesh. However, reliability and access to service are found to have insignificant influence on customer satisfaction. In addiction, $\mathrm{Li}, \mathrm{Lu}, \mathrm{Hou}, \mathrm{Cui}, \&$ Darbandi (2021) found that serice quality as asingle construct is asignficant predictor of customer satisfaction $\mathrm{n}$ using Internet banking services in China.

It is worthy to mention that the study of Al-Azzam (2015) is the closest to this study, but it differs from it in application and the social environment in Jordan differs from the Kingdom of Saudi Arabia, in addition to the difference in the banking system between the two countries in terms of organizing laws, and the administrative foundations used in the management of banks. The independent variable of the study is the quality of electronic banking services and the focus on tangibility, reliability, safety, security and responsiveness. Tangibles include physical facilities, equipment, personnel and communication technologies. Tangibles are one of the basic components of the quality of electronic service. Reliability reflects the ability of the service provider to perform the service reliably and accurately, and it includes the services as promised at fixed, agreed time. Reliability reflects the ability of the service provider to perform the service reliably and accurately, and it includes the services as promised at fixed, agreed time. Security: This means reassurance from customers that the service 
provided to them is free from error, danger, and the ability of the bank and its employees to build up and gain customers' confidence. Response: means the ability and desire to help customers and provide quick service to them, as it expresses the ability of the bank to provide everything that can assist customers. Empathy: the degree of care that the bank pays to its customers, taking care of their problems and finding solutions to them. The dependent variable is customer satisfaction.

\section{Method}

This study utilized the quantitative approach through a case study based on collecting information through a well-articulated questionnaire for this purpose in an objective manner to study hypotheses and draw conclusions and recommendations, in addition to observation to survey opinions from the reality of experience. It used SPSS to nalyze the data o study. The study population consists of all dealers with Al Rajhi Bank branches in the city of Dawadmi, Kingdom of Saudi Arabia, during the year 2021. A random sample was selected from those dealing with Link Al-Rajhi in the city of Dawadmi, and the study sample size was 100 customers which used in the final analysis. In this study, the researcher used a questionnaire that was prepared for this study, and it included 50 items. The demographic profile of the respondents can be shown in Table 1 below.

Table 1. Demographic profile of the respondents

\begin{tabular}{llll}
\hline Phrase & phrase axes & Frequency & Percentage \\
\hline Type & Male & 70 & $70 \%$ \\
& Female & 30 & $30 \%$ \\
Age & $(20-30)$ & 44 & $44.0 \%$ \\
& $(31-40)$ & 20 & $20.0 \%$ \\
& $(41-50)$ & 16 & $16.0 \%$ \\
Educational level & ( more than 50) & 20 & $20.0 \%$ \\
& Diploma / Secondary & 62 & $61.0 \%$ \\
& Master's & 24 & $24.0 \%$ \\
Years of dealing with the bank & PhD & 14 & $14.0 \%$ \\
& Other & 4 & $4.0 \%$ \\
& $(1-5)$ & 48 & $\% 48.0$ \\
& $(6-10)$ & 40 & $40.0 \%$ \\
& $($ more than 10 ) & 12 & $12.0 \%$ \\
\hline
\end{tabular}

It was found that the number of males $(70 \%)$ is more than the number of females in a sample due to the nature of Saudi society, and that the youth group is one of the most $(40 \%)$. The groups dealing with the bank for the electronic services provided by the bank. The study also focused on the different educational levels in order to include the study sample, but the majority are high school holders. As for the years of dealing with the bank, it was found that the number of respondents who dealt with the bank in a period of less than (10 years) are the most, and this indicates that the bank has updated its services and added new electronic services.

The questionnaire was built on the five-point Likert scale, as the scores were given as shown in the table below:

Table 2. Five-point Likert Scale

\begin{tabular}{lll}
\hline Scale phrases & Class & Weight attributable to measuring average \\
\hline Strongly Agree & 5 & $4.80-5.00$ \\
OK & 4 & $3.80-4.79$ \\
Neutral & 3 & $2.80-3.79$ \\
not agree & 2 & $1.80-2.79$ \\
Strongly Disagree & 1 & less than 1.80 \\
\hline
\end{tabular}

\section{Results}

The validity of the tool was verified by presenting it to a group of specialized and experienced arbitrators from faculty members in Saudi and Arab universities, as well as a number of quality experts. Made up of 40 phrases. The stability of the tool was verified by using Cronbach's alpha equation, where the overall reliability coefficient was (0.953). It is a value that satisfies the purposes of this study. 
Table 3. The Alpha cronbach Scale to measure the validity of the questionnaire statements

\begin{tabular}{lll}
\hline Alpha Cronbach & Cronbach's Alpha Based on Standardized Items & No. of Items \\
\hline .953 & .953 & 40 \\
\hline
\end{tabular}

Table 4 below also shows that the terms of the axis of tangibility (physical facilities and equipment); They tend to agree, as the total general average of the weighted arithmetic mean for the axis is 4.00 , which is a high percentage, and the standard deviation is .52270 , i.e. less than one, which is a percentage that shows the extent of homogeneity of the respondents' answers. Statement No. (1) and No. (6) represent the highest average of the question phrases, which is 4.40 , and the highest standard deviation is 0.495 , and that the approval percentage reached $100 \%$ in statement (1), and this indicates the availability of ATMs and the appropriateness of their geographical locations for the respondents.

Table 4. The first axis: tangibility (physical facilities and equipment

\begin{tabular}{|c|c|c|c|c|c|c|c|c|}
\hline Axis phrases & 5 & 4 & 3 & 2 & 1 & $\begin{array}{l}\text { Arithmetic } \\
\text { mean }\end{array}$ & $\begin{array}{l}\text { standard } \\
\text { deviation }\end{array}$ & $\begin{array}{l}\text { The } \\
\text { result }\end{array}$ \\
\hline $\begin{array}{l}\text { The bank has advanced and high-tech equipment and } \\
\text { supplies }\end{array}$ & $\begin{array}{l}20 \\
40\end{array}$ & $\begin{array}{l}30 \\
60\end{array}$ & $\begin{array}{l}0 \\
\% 0\end{array}$ & $\begin{array}{l}0 \\
\% 0\end{array}$ & $\begin{array}{l}0 \\
\% 0\end{array}$ & 4.40 & .495 & positive \\
\hline $\begin{array}{l}\text { The parking and lounges are good and attractive to } \\
\text { customers }\end{array}$ & $\begin{array}{l}10 \\
\% 20\end{array}$ & $\begin{array}{l}18 \\
\% 36\end{array}$ & $\begin{array}{l}8 \\
\% 16\end{array}$ & $\begin{array}{l}12 \\
\% 24\end{array}$ & $\begin{array}{l}2 \\
\% 4\end{array}$ & 3.44 & 1.181 & positive \\
\hline $\begin{array}{l}\text { Bank employees have a good appearance that attracts } \\
\text { customers }\end{array}$ & $\begin{array}{l}12 \\
\% 24\end{array}$ & $\begin{array}{l}24 \\
\% 48\end{array}$ & $\begin{array}{l}12 \\
\% 24\end{array}$ & $\begin{array}{l}2 \\
\% 4\end{array}$ & $\begin{array}{l}0 \\
\% 0\end{array}$ & 3.92 & .804 & positive \\
\hline $\begin{array}{l}\text { The general appearance of the bank is consistent with } \\
\text { the nature of the services it provides to clients }\end{array}$ & $\begin{array}{l}14 \\
\% 28\end{array}$ & $\begin{array}{l}24 \\
\% 48\end{array}$ & $\begin{array}{l}12 \\
\% 24\end{array}$ & $\begin{array}{l}0 \\
\% 0\end{array}$ & $\begin{array}{l}0 \\
\% 0\end{array}$ & 4.04 & .727 & positive \\
\hline $\begin{array}{l}\text { The design of the building and its internal arrangement } \\
\text { facilitate the process of obtaining the service }\end{array}$ & $\begin{array}{l}12 \\
\% 24\end{array}$ & $\begin{array}{l}30 \\
\% 60\end{array}$ & $\begin{array}{l}8 \\
\% 16\end{array}$ & $\begin{array}{l}0 \\
\% 0\end{array}$ & $\begin{array}{l}0 \\
\% 0\end{array}$ & 4.08 & .634 & positive \\
\hline $\begin{array}{l}\text { Automated teller machines (ATMs) are available in } \\
\text { locations that suit the bank's customers }\end{array}$ & $\begin{array}{l}22 \\
\% 44\end{array}$ & $\begin{array}{l}24 \\
\% 48\end{array}$ & $\begin{array}{l}0 \\
\% 0\end{array}$ & $\begin{array}{l}4 \\
\% 8\end{array}$ & $\begin{array}{l}0 \\
\% 0\end{array}$ & 4.28 & .834 & positive \\
\hline Self-service machines are available in all bank branches & $\begin{array}{l}14 \\
\% 28\end{array}$ & $\begin{array}{l}24 \\
\% 48\end{array}$ & $\begin{array}{l}4 \\
\% 8\end{array}$ & $\begin{array}{l}6 \\
\% 12\end{array}$ & $\begin{array}{l}2 \\
\% 4\end{array}$ & 4.40 & .495 & positive \\
\hline axis result & 104 & 174 & 44 & 24 & 4 & 4.0000 & .52270 & positive \\
\hline
\end{tabular}

Notes. $5=\mathrm{I}$ totally agree, $4=\mathrm{I}$ agree, $3=$ Neutral, $2 \mathrm{I}$ do not agree $=, 1=$ Strongly Disagree.

Table 5 below also shows that the accreditation axis phrases (the ability to perform the service accurately); They tend to agree, as the total general average of the weighted arithmetic mean for the axis is 4.0560 , which is a high percentage, and the standard deviation is .54666 , i.e. less than one, which is a statistically acceptable percentage and indicates that the respondents' opinion on these statements tends to agree, and statement No. (3) It represents the highest average of the question phrases, which is 4.20 , and the percentage of approval is $84 \%$, and this indicates the respondents' approval that the bank performs the service on the agreed date. 
Table 5. The Second Axis: Accreditation (reliability and the ability to perform the service accurately

\begin{tabular}{|c|c|c|c|c|c|c|c|c|}
\hline Axis phrases & 5 & 4 & 3 & 2 & 1 & $\begin{array}{l}\text { Aritmetic } \\
\text { mean }\end{array}$ & $\begin{array}{l}\text { standard } \\
\text { deviation }\end{array}$ & $\begin{array}{l}\text { The } \\
\text { result }\end{array}$ \\
\hline $\begin{array}{l}\text { The bank is obligated to perform business at the } \\
\text { specified times }\end{array}$ & $\begin{array}{l}18 \\
\% 36\end{array}$ & $\begin{array}{l}24 \\
\% 48\end{array}$ & $\begin{array}{l}6 \\
\% 12\end{array}$ & $2 \%$ & $\begin{array}{l}0 \\
\% 0\end{array}$ & 3.84 & 1.095 & positive \\
\hline $\begin{array}{l}\text { The bank performs the service correctly and from the } \\
\text { first time }\end{array}$ & $\begin{array}{l}16 \\
\% 32\end{array}$ & $\begin{array}{l}30 \\
\% 60\end{array}$ & $\begin{array}{l}2 \\
\% 4\end{array}$ & $\begin{array}{l}2 \\
\% 4\end{array}$ & $\begin{array}{l}0 \\
\% 0\end{array}$ & 4.16 & .792 & positive \\
\hline The bank performs the service on the agreed date & $\begin{array}{l}12 \\
\% 24\end{array}$ & $\begin{array}{l}30 \\
\% 60\end{array}$ & $\begin{array}{l}8 \\
\% 16\end{array}$ & $\begin{array}{l}0 \\
\% 0\end{array}$ & $\begin{array}{l}0 \\
\% 0\end{array}$ & 4.20 & .700 & positive \\
\hline $\begin{array}{l}\text { The Bank maintains clear and accurate account } \\
\text { records }\end{array}$ & $\begin{array}{l}16 \\
\% 32\end{array}$ & $\begin{array}{l}28 \\
\% 56\end{array}$ & $\begin{array}{l}4 \\
\% 8\end{array}$ & 2 & $\%$ & 4.08 & .634 & positive \\
\hline $\begin{array}{l}\text { The bank employs distinguished expertise to rely on } \\
\text { them to provide high quality services }\end{array}$ & $\begin{array}{l}8 \\
\% 16\end{array}$ & $\begin{array}{l}22 \\
\% 44\end{array}$ & $\begin{array}{l}16 \\
\% 32\end{array}$ & $\begin{array}{l}4 \\
\% 8\end{array}$ & $\begin{array}{l}0 \\
\% 0\end{array}$ & 4.16 & .738 & positive \\
\hline axis result & 70 & 134 & 36 & 10 & 0 & 4.0560 & .54666 & positive \\
\hline
\end{tabular}

Notes. $5=$ I totally agree, $4=$ I agree, $3=$ Neutral , 2 I do not agree $=$, $1=$ Strongly Disagree.

Table 6 below also shows that the phrases of the axis of safety (guarantee, honesty and reassurance); They tend to agree, as the total general average of the weighted arithmetic mean for the axis is 3.9440 , which is a high percentage, and the standard deviation is .57006 , i.e. less than one, which is a statistically acceptable percentage and indicates that the respondents' opinion on these statements tends to agree, and statement No. (4) The highest average of the question phrases is 4.28 , the highest standard deviation is 0.671 , and the approval rate is $88 \%$, and this indicates the respondents' agreement that the bank has an electronic system that protects customer data.

Table 6. The third axis: safety (guarantee, honesty and reassurance)

\begin{tabular}{|c|c|c|c|c|c|c|c|c|}
\hline Axis phrases & 5 & 4 & 3 & 2 & 1 & $\begin{array}{l}\text { Arithmetic } \\
\text { mean }\end{array}$ & $\begin{array}{l}\text { standard } \\
\text { deviation }\end{array}$ & $\begin{array}{l}\text { The } \\
\text { result }\end{array}$ \\
\hline \multirow[t]{2}{*}{ Bank employees can be trusted } & 8 & 26 & 16 & 0 & 0 & 3.84 & .681 & positive \\
\hline & $\% 16$ & $\% 52$ & $\% 32$ & $\% 0$ & $\% 0$ & & & \\
\hline \multirow[t]{2}{*}{ I feel safe when dealing with bank employees } & 14 & 18 & 18 & 0 & 0 & 3.92 & .804 & positive \\
\hline & $\% 28$ & $\% 36$ & $\% 36$ & $\% 0$ & $\% 0$ & & & \\
\hline \multirow{2}{*}{$\begin{array}{l}\text { The bank's employees have enough knowledge to } \\
\text { answer various customer questions }\end{array}$} & 12 & 26 & 8 & 4 & 0 & 3.92 & .853 & positive \\
\hline & $\% 24$ & $\% 52$ & $\% 16$ & $\% 8$ & $\% 0$ & & & \\
\hline \multirow{2}{*}{$\begin{array}{l}\text { The bank has an electronic system that protects } \\
\text { customer data }\end{array}$} & 20 & 24 & 6 & 0 & 0 & 4.28 & .671 & positive \\
\hline & $\% 40$ & $\% 48$ & $\% 12$ & $\% 0$ & $\% 0$ & & & \\
\hline \multirow{3}{*}{$\begin{array}{l}\text { Data can be recovered in the event of an information } \\
\text { breach } \\
\text { axis result }\end{array}$} & 14 & 12 & 22 & 2 & 0 & 3.76 & .916 & positive \\
\hline & $\% 28$ & $\% 24$ & $\% 44$ & 4 & $\% 0$ & & & \\
\hline & 68 & 106 & 62 & 6 & 0 & 3.9440 & .57006 & positive \\
\hline
\end{tabular}

Notes. $5=$ I totally agree, $4=$ I agree, $3=$ Neutral , 2 I do not agree $=, 1=$ Strongly Disagree.

Table 7 reveals that most of customers tend to agree, as the total general average of the weighted arithmetic mean for the axis is 3.6080, which is an acceptable ratio, and the standard deviation is .76980, i.e. less than one, which is a statistically acceptable percentage and indicates that the respondents' opinion on these statements tends to agree, and statement No. (2) The highest average of the question phrases is 3.80, and the percentage of approval is $68 \%$, and this indicates the respondents' agreement that the bank's employees are distinguished by tact. 
Table 7. The Fourth Axis: Empathy (understanding and caring for customers)

\begin{tabular}{|c|c|c|c|c|c|c|c|c|}
\hline Axis phrases & 5 & 4 & 3 & 2 & 1 & $\begin{array}{l}\text { Arithmetic } \\
\text { mean }\end{array}$ & $\begin{array}{l}\text { standard } \\
\text { deviation }\end{array}$ & $\begin{array}{l}\text { The } \\
\text { result }\end{array}$ \\
\hline \multirow[t]{2}{*}{ The bank takes care of customers' problems } & 6 & 24 & 16 & 4 & 0 & 3.64 & .802 & positive \\
\hline & $\% 12$ & $\% 48$ & $\% 32$ & $\% 8$ & $\% 0$ & & & \\
\hline \multirow[t]{2}{*}{ Bank employees are courteous } & 10 & 24 & 12 & 4 & 0 & 3.80 & .857 & positive \\
\hline & $\% 20$ & $\% 48$ & $\% 24$ & $\% 8$ & $\% 0$ & & & \\
\hline \multirow{2}{*}{$\begin{array}{l}\text { The bank has a lounge supervisor who helps and } \\
\text { guides customers }\end{array}$} & 8 & 14 & 18 & 6 & 4 & 3.32 & 1.133 & positive \\
\hline & $\% 16$ & $\% 28$ & $\% 36$ & $\% 12$ & $\% 8$ & & & \\
\hline \multirow{2}{*}{$\begin{array}{l}\text { The employee assists customers with special needs } \\
\text { and provides them with services }\end{array}$} & 8 & 20 & 20 & 2 & 0 & 3.64 & .898 & positive \\
\hline & $\% 16$ & $\% 40$ & $\% 40$ & $\% 4$ & $\% 0$ & & & \\
\hline \multirow{2}{*}{$\begin{array}{l}\text { The bank answers customer inquiries in a timely } \\
\text { manner }\end{array}$} & 8 & 24 & 14 & 4 & 0 & 3.64 & 1.025 & positive \\
\hline & $\% 16$ & $\% 48$ & $\% 28$ & $\% 8$ & $\% 0$ & & & \\
\hline axis result & 40 & 106 & 80 & 20 & 4 & 3.6080 & .76980 & positive \\
\hline
\end{tabular}

Notes. $5=$ I totally agree, $4=$ I agree, $3=$ Neutral , 2 I do not agree =, 1= Strongly Disagree.

Table 8 above shows that the response axis phrases (readiness to help customers and provide quick services); They tend to agree, as the total general average of the weighted arithmetic mean for the axis is 3.6533, which is an acceptable ratio, and the standard deviation is .54277 , i.e. less than one, which is a statistically acceptable percentage and indicates that the respondents' opinion on these statements tends to agree, and statement No. (6) The highest average of the question phrases is 4.08 , meaning that the approval rate is $80 \%$, and this indicates the respondents' approval that the bank provides self-service devices to customers.

Table 8 . The fifth axis: response (readiness to help clients and provide quick services)

\begin{tabular}{|c|c|c|c|c|c|c|c|c|}
\hline Axis phrases & 5 & 4 & 3 & 2 & 1 & $\begin{array}{l}\text { Arithmetic } \\
\text { mean }\end{array}$ & $\begin{array}{l}\text { standard } \\
\text { deviation }\end{array}$ & $\begin{array}{l}\text { The } \\
\text { result }\end{array}$ \\
\hline $\begin{array}{l}\text { The bank determines the exact time of completion of } \\
\text { the service }\end{array}$ & $\begin{array}{l}4 \\
\% 8\end{array}$ & $\begin{array}{l}26 \\
\% 52\end{array}$ & $\begin{array}{l}16 \\
\% 32\end{array}$ & $\begin{array}{l}4 \\
\% 8\end{array}$ & $\begin{array}{l}0 \\
\% 0\end{array}$ & 3.60 & .756 & Positive \\
\hline The service is provided to customers immediately & $\begin{array}{l}6 \\
\% 12\end{array}$ & $\begin{array}{l}20 \\
\% 40\end{array}$ & $\begin{array}{l}18 \\
\% 36\end{array}$ & $\begin{array}{l}6 \\
\% 12\end{array}$ & $\begin{array}{l}0 \\
\% 12\end{array}$ & 3.52 & .863 & Positive \\
\hline $\begin{array}{l}\text { The bank's employees are always ready to help } \\
\text { customers }\end{array}$ & $\begin{array}{l}8 \\
\% 16\end{array}$ & $\begin{array}{l}22 \\
\% 44\end{array}$ & $\begin{array}{l}16 \\
\% 32\end{array}$ & $\begin{array}{l}4 \\
\% 8\end{array}$ & $\begin{array}{l}0 \\
\% 0\end{array}$ & 3.64 & .898 & Positive \\
\hline $\begin{array}{l}\text { Bank employees respond to requests immediately, } \\
\text { no matter how busy they are }\end{array}$ & $\begin{array}{l}6 \\
\% 12\end{array}$ & $\begin{array}{l}20 \\
\% 40\end{array}$ & $\begin{array}{l}14 \\
\% 28\end{array}$ & $\begin{array}{l}10 \\
\% 20\end{array}$ & $\begin{array}{l}0 \\
\% 0\end{array}$ & 3.44 & .951 & Positive \\
\hline $\begin{array}{l}\text { There are devices that regulate the movement of } \\
\text { customers and direct them }\end{array}$ & $\begin{array}{l}6 \\
\% 12\end{array}$ & $\begin{array}{l}30 \\
60\end{array}$ & $\begin{array}{l}6 \\
\% 12\end{array}$ & $\begin{array}{l}6 \\
\% 12\end{array}$ & $\begin{array}{l}2 \\
\% 4\end{array}$ & 3.64 & .985 & Positive \\
\hline Self-service machines are available to customers & $\begin{array}{l}16 \\
\% 32\end{array}$ & $\begin{array}{l}24 \\
\% 48\end{array}$ & $\begin{array}{l}18 \\
\% 36\end{array}$ & $\begin{array}{l}2 \\
\% 4\end{array}$ & $\begin{array}{l}0 \\
\% 0\end{array}$ & 4.08 & .804 & Positive \\
\hline axis result & 46 & 142 & 86 & 32 & 2 & 3.6533 & .54277 & Positive \\
\hline
\end{tabular}

Notes. $5=$ I totally agree, $4=$ I agree, $3=$ Neutral , 2 I do not agree $=, 1=$ Strongly Disagree.

Table 9 below shows that the terms of customer satisfaction axis; They tend to agree, as the total general average of the weighted arithmetic mean for the axis is 3.8550, which is a statistically acceptable ratio, and the standard deviation is .57994 , i.e. less than one, which is a statistically acceptable percentage. 2) It represents the highest average of the axis phrases, which is 4.20 , meaning that the approval rate is $88 \%$, and this indicates the approval of the respondents that the bank's employees speed up the completion of the service for customers and this achieves their satisfaction. 
Table 9. The Sixth Axis: Customer Satisfaction

\begin{tabular}{|c|c|c|c|c|c|c|c|c|}
\hline Axis phrases & 5 & 4 & 3 & 2 & 1 & $\begin{array}{l}\text { Arithmetic } \\
\text { mean }\end{array}$ & $\begin{array}{l}\text { standard } \\
\text { deviation }\end{array}$ & $\begin{array}{l}\text { The } \\
\text { result }\end{array}$ \\
\hline $\begin{array}{l}\text { The bank has attractive buildings and advanced computer } \\
\text { equipment }\end{array}$ & $\begin{array}{l}16 \\
\% 32\end{array}$ & $\begin{array}{l}20 \\
\% 40\end{array}$ & $\begin{array}{l}10 \\
\% 20\end{array}$ & $\begin{array}{l}4 \\
\% 8\end{array}$ & $\begin{array}{l}0 \\
\% 0\end{array}$ & 3.96 & .925 & positive \\
\hline $\begin{array}{l}\text { The speed of service delivery achieves customer } \\
\text { satisfaction }\end{array}$ & $\begin{array}{l}20 \\
\% 40\end{array}$ & $\begin{array}{l}22 \\
\% 44\end{array}$ & 6 & $\begin{array}{l}2 \\
\% 4\end{array}$ & $\begin{array}{l}0 \\
\% 0\end{array}$ & 4.20 & .808 & positive \\
\hline $\begin{array}{l}\text { The bank provides high-level services to its customers } \\
\text { with the aim of satisfying them }\end{array}$ & $\begin{array}{l}8 \\
\% 16\end{array}$ & $\begin{array}{l}28 \\
\% 56\end{array}$ & $\begin{array}{l}12 \\
\% 24\end{array}$ & $\begin{array}{l}2 \\
\% 4\end{array}$ & $\begin{array}{l}0 \\
\% 0\end{array}$ & 3.84 & .738 & positive \\
\hline $\begin{array}{l}\text { The bank provides a level of after-sales services that } \\
\text { increases customer loyalty to the bank }\end{array}$ & $\begin{array}{l}4 \\
\% 8\end{array}$ & $\begin{array}{l}20 \\
\% 40\end{array}$ & $\begin{array}{l}22 \\
\% 46\end{array}$ & $\begin{array}{l}4 \\
\% 8\end{array}$ & $\begin{array}{l}0 \\
\% 0\end{array}$ & 3.48 & .762 & positive \\
\hline The type of offered services meet customer requirements & $\begin{array}{l}8 \\
\% 16\end{array}$ & $\begin{array}{l}20 \\
\% 40\end{array}$ & $\begin{array}{l}18 \\
\% 38\end{array}$ & $\begin{array}{l}4 \\
\% 8\end{array}$ & $\begin{array}{l}0 \\
\% 0\end{array}$ & 3.64 & .851 & positive \\
\hline $\begin{array}{l}\text { The accuracy of service delivery achieves customer } \\
\text { satisfaction }\end{array}$ & $\begin{array}{l}16 \\
\% 32\end{array}$ & $\begin{array}{l}20 \\
40\end{array}$ & $\begin{array}{l}10 \\
\% 20\end{array}$ & $\begin{array}{l}4 \\
\% 8\end{array}$ & $\begin{array}{l}0 \\
\% 0\end{array}$ & 3.96 & .925 & positive \\
\hline $\begin{array}{l}\text { The bank provides the promised services to customers, } \\
\text { which contributes to enhancing their satisfaction }\end{array}$ & $\begin{array}{l}14 \\
\% 28\end{array}$ & $\begin{array}{l}22 \\
\% 44\end{array}$ & $\begin{array}{l}12 \\
\% 24\end{array}$ & $\begin{array}{l}2 \\
\% 4\end{array}$ & $\begin{array}{l}0 \\
\% 0\end{array}$ & 3.92 & .944 & positive \\
\hline $\begin{array}{l}\text { Employees treat themselves with credibility, which } \\
\text { enhances customer satisfaction }\end{array}$ & $\begin{array}{l}10 \\
\% 20\end{array}$ & $\begin{array}{l}24 \\
\% 48\end{array}$ & $\begin{array}{l}14 \\
28\end{array}$ & $\begin{array}{l}2 \\
\% 4\end{array}$ & $\begin{array}{l}0 \\
\% 0\end{array}$ & 3.84 & .792 & positive \\
\hline Axis result & 96 & 176 & 104 & 24 & 0 & 3.8550 & .57994 & positive \\
\hline
\end{tabular}

Notes. $5=$ I totally agree, $4=$ I agree, $3=$ Neutral , 2 I do not agree $=, 1=$ Strongly Disagree.

Table 10 above shows that the level of the significant value in all axes of the study is equal to 0.00, i.e. less than 0.05 , and this indicates the consent of the respondents to the alternative hypotheses of the chi-squared test that supports the statistical decision of the axes in the above tables, which indicates the level of congruence in the respondents' answers to Their satisfaction with the level of quality of electronic services provided by Al Rajhi Bank.

Table 10. The Measuring the level of congruence between the expressions of the questionnaire axes according to chi-squared and the level of significance

\begin{tabular}{llll}
\hline Axles & $\begin{array}{l}\text { chi-squared test } \\
\text { Chi-Square }\end{array}$ & $\begin{array}{l}\text { Moral value } \\
\text { Asymp. Sig. }\end{array}$ & $\begin{array}{l}\text { Statistical decision } \\
\text { statistically significant } \\
\text { statistically significant }\end{array}$ \\
\hline $\begin{array}{l}\text { The first axis: tangibility (physical facilities and equipment) } \\
\text { The second axis: accreditation (reliability and the ability to } \\
\text { perform the service accurately) }\end{array}$ & .000 & .000 & statistically significant \\
The third axis: Empathy (understanding and caring for & $84.281^{\text {a }}$ & .000 & statistically significant \\
customers) & & .000 & .000 \\
$\begin{array}{l}\text { Fourth Axis: Empathy (understanding and caring for customers) } \\
\text { The fifth axis: response and readiness to help customers and } \\
\text { provide quick services }\end{array}$ & $190.442^{\mathrm{a}}$ & & .000 \\
Sixth Axis: Customer Satisfaction & $115.840^{\mathrm{a}}$ & & statistically significant \\
\hline
\end{tabular}

\section{Discussion and Conclusion}

The aim of this study is to examine the effect of electronic banking service quality on the customer satisfaction by the customers of Al-Rajhi bank. The results found that the physical facilities and equipment of Al Rajhi Bank are available to a high degree, which can achieve the satisfaction of its customers; The general mean of the weighted arithmetic mean for the axis was 4.00, which is a high percentage, and the standard deviation is .52270 , which is a statistically acceptable percentage. Al-Rajhi Bank has also the ability to perform the service accurately in order to satisfy its customers, as the total general average of the weighted arithmetic mean for the axis is 4.0560, which is a high percentage, and the standard deviation is .54666 , which is a statistically acceptable ratio. Moreover, there is a relationship between the speed of response to customers and customer satisfaction in Al Rajhi Bank through the respondents' answers to the hypothesis questions at a high rate through the general average of 3.77 , and the standard deviation of 0.995 , which is a statistically acceptable percentage. In 
addition, Al-Rajhi Bank has a security service in bank accounts to preserve the rights of customers, as the total general average of the weighted arithmetic mean for the axis is 3.9440, which is a high percentage, and the standard deviation is .57006 , which is a statistically acceptable ratio.

Similarly, the bank appreciates and understands customers and cares for them by providing a service that meets their aspirations, as the general average of the weighted arithmetic mean for the axis was 3.6080, which is an acceptable ratio, and the standard deviation is .76980 , which is a statistically acceptable ratio. The bank is also preparing to help its customers and provide quick services to them that will satisfy them, as the general average of the weighted arithmetic mean for the axis reached 3.6533, which is an acceptable ratio, and the standard deviation is .54277 , which is a statistically acceptable ratio. In a similar way, Al-Rajhi Bank's customer satisfaction reached a high percentage, as the total general average of the weighted arithmetic mean for the axis is 3.8550 , which is a statistically acceptable percentage, and the standard deviation is .57994 , which is a statistically acceptable percentage.

This study suggests that paying attention to customer satisfaction and fascinating them with the level of services provided, as well as realizing their aspirations, because it is the ideal way to achieve the bank's goals. Reviewing the electronic banking services provided by Al Rajhi Bank, especially the security service, and addressing its shortcomings. Focus on new and old clients and major clients, as well as clients expected to deal with the bank in the future. Interest in developing the electronic infrastructure of the bank through the development of electronic services. Conducting more studies and research in this field in order to develop the bank and achieve its goals and the goals of its employees and those dealing with it efficiently and effectively.

\section{References}

Abu al-Naga, A. M. (2008). Advanced Marketing. Alexandria, University House.

Ahmed, A. M. (2001). Marketing of Banking Services (1st ed.). Amman: Dar Al-Baraka for Publishing and Distribution.

Al Muhaidib, R. A. (2017). Customer and Beneficiary Satisfaction (1st ed.). Riyadh: Development and Educational Resources Platform.

Al-Azzam, A. F. M. (2015). The impact of service quality dimensions on customer satisfaction: A field study of Arab bank in Irbid city, Jordan. European Journal of Business and Management, 7(15), 45-53. Retrieved from https://citeseerx.ist.psu.edu/viewdoc/download?doi=10.1.1.736.3256\&rep=rep1\&type=pdf

Al-Giashi, A. A., \& Haddad, S. I. (2010). Modeling the Relationship Between Service Perception and Customer Loyalty as Quality, A Field Study in the Commercial Banks Sector in Jordan. Dirasat Journal, 37(2), 309-334. Retrieved from https://journals.ju.edu.jo/DirasatAdm/article/view/1578/6210

Alolayyan, M. N., Al-Hawary, S. I. S., Mohammad, A. A. S., \& Al-Nady, B. A. H. A. (2018). Banking service quality provided by commercial banks and customer satisfaction. A structural equation modelling approaches. International Journal of Productivity and Quality Management, 24(4), 543-565. https://doi.org/10.1504/IJPQM.2018.10014459

Al-Sarn, R. H. (2007). Globalization of the Quality of Banking Services (1st ed.). Amman: Al-Warraq for Publishing and Distribution.

Al-Tai ,H., \& Al-Alaqi, B. (2015). Quality of Service, Jordan: A Study on Jordanian Banks.

Black, M. (2016). The Impact of Quality of Banking Services on Customer Satisfaction in Bank of Syria and Overseas (Unpublished Dissetation). Syrian Virtual University, Syria.

Daradkeh, M. (2006). Total Quality Management and Customer Service (1st ed.). Oman, Dar Al-Safa.

Islam, R., Ahmed, S., Rahman, M., \& Al Asheq, A. (2021). Determinants of service quality and its effect on customer satisfaction and loyalty: an empirical study of private banking sector. The TQM Journal, 33(6), 1163-1182. https://doi.org/10.1108/TQM-05-2020-0119

Li, F., Lu, H., Hou, M., Cui, K., \& Darbandi, M. (2021). Customer satisfaction with bank services: The role of cloud services, security, e-learning and service quality. Technology in Society, 64, 101487. https://doi.org/10.1016/j.techsoc.2020.101487

Nguyen, D. T., Pham, V. T., Tran, D. M., \& Pham, D. B. T. (2020). Impact of service quality, customer satisfaction and switching costs on customer loyalty. The Journal of Asian Finance, Economics, and Business, 7(8), 395-405. https://doi.10.13106/jafeb.2020.vol7.no8.395

Ozkan, P., S., Suer, S., Keser, I. K., \& Kocakoç, I. D. (2020). The effect of service quality and customer 
satisfaction on customer loyalty: the mediation of perceived value of services, corporate image, and corporate reputation. International Journal of Bank Marketing, 38(2), 384-405. https://doi.org/10.1108/IJBM-03-2019-0096

Um Al-Khair, B. (2016). The Role of Banking Services and Its Impact on Customer Satisfaction, An Applied Study on the Bank of Algeria - External Clients. Algeria: University: Kasdi Merbah - Ouargla.

\section{Copyrights}

Copyright for this article is retained by the author(s), with first publication rights granted to the journal.

This is an open-access article distributed under the terms and conditions of the Creative Commons Attribution license (http://creativecommons.org/licenses/by/4.0/). 